Nepal Journal of Multidisciplinary Research (NJMR)

Vol. 4, No. 4, December 2021. Pages: 63-69

ISSN: 2645-8470 (Print), ISSN: 2705-4691 (Online)

DOI: https://doi.org/10.3126/njmr.v4i4.43210

\title{
HRM Practices and its Impact on Customers' Satisfaction of Pharmaceutical Companies in Nepal
}

\author{
Dr.Tara Prashad Gautam \\ Researcher, Nepal Philosophical Research Center \\ tara2jun@gmail.com
}

Received: November 28, 2021; Revised \& Accepted: December 29, 2021

(C) Copyright: Gautam (2021).

(c) (1) (8)

This work is licensed under a Creative Commons Attribution-Non Commercial $\underline{4.0}$ International License.

\begin{abstract}
This paper aims to investigate the HRM practices and impact on Customers satisfaction in the pharmaceutical companies of Nepal A structured questionnaire was developed and distributed among 386 employees of 37pharmaceuticals companies. Statistical correlation analysis was used to assess the impact of HRM practices on Customer satisfaction. The study reveals that employees in pharmaceutical companies are satisfied with the recruitment and selection, and training and development policy and practices of pharmaceutical companies. On the other hand, employees are dissatisfied with the human resource planning, working environment, compensation policy, performance appraisal, and industrial relations. The study suggests that the pharmaceutical companies should develop proper human resource policy and given emphasis on proper human resource practices to enhance the satisfaction of their customer and build them effective human resources.
\end{abstract}

Keywords: Human resource management practice, Customers satisfaction, Pharmaceutical

\section{Introduction}

Pharmaceuticals industry is a rising economic sector in Nepal It produces and design pharmaceutical products are drugs, infusion products, and medical equipment's. The product is not confined only open sale but it also deals with doctors, nurses, hospitals, pharmacist and researchers for further development. Bangladeshi pharmaceuticals companies produce products not only for the home country but also they are exporting their medicine to Australia, Brazil, Afghanistan, Cambodia, Guyana, Jordan, Kenya, Malaysia, Myanmar, Nepal, Philippines, Hong Kong, Sri Lanka, Vietnam, United Kingdom, and among others. This trend of exporting volume and profit generation is up warding. There are 250 licensed pharmaceutical companies in the economy and they are contributing $1 \%$ in gross domestic product (GDP). Top 20 companies earned 80\% revenue in 2011. 


\title{
Nepal Journal of Multidisciplinary Research (NJMR)
}

\author{
Vol. 4, No. 4, December 2021. Pages: 63-69 \\ ISSN: 2645-8470 (Print), ISSN: 2705-4691 (Online) \\ DOI: https://doi.org/10.3126/njmr.v4i4.43210
}

Human resource management (henceforth HRM) is the effective management of people at work. Beardwell, Holden \& Claydon (2004) regard HRM as the philosophy, policies, procedures, and practices related to the management of people within the organization. Senyucels (2012) sees HRM as a combination of people centered management practices that recognize employees as assets geared to creating and maintaining skillful and committed workforce for achieving organizational goals. Mondy and Noe (2005) believe that HRM is the utilization of individuals to achieve organizational objectives. Denishi and Griffin (2009) suggest that HRM is the comprehensive set of managerial activities and tasks concerned with developing and maintaining a qualified workforce. Human resource is a way that contributes to organizational effectiveness. In most of today's organizations, the role of HRM has become quite important (Blake 1995).

Agrawal (1977) characterized the Nepalese management environment as the art and science of avoiding decisions, blocking the job through delaying, do nothing and mismanaging. Similarly, Rana (1971, cited in Gautam, 2003) stated the limitation factor as management, not the capital in Nepal. Upadhyay (1981) found a low level of employees' morale and Koirala (1989) found the poor state of employees' participation in Nepalese organizations. Pant (1984) observed tradition bound, unilateral and authoritative system of management in Nepalese organizations.

Pradhan (1988) reported that management professionalism has not yet been seen in neither of the sectors because of lack of awareness and sense of commitment in the public sector and lack of initiative in the private sector. Similarly, Paudel (1992) reported that management is almost feudalistic and decision-making even on minor issues is centralized in Nepalese public sector. Few such climate factors as security, participation, warmth, and support explained job satisfaction in Nepalese context (Pradhan, 1999). Adhikari (2000) characterized Nepalese human resources management handicapped by the prevailing management norms and culture. The above literature review shows that there have been several studies on HRM practices and job satisfaction. In Bangladesh, however, there is a research gap in this area especially on pharmaceuticals companies. Hence, the study is undertaken. To find out the impact of HRM practices on employee's job satisfaction, the human resource planning, working environment, training and development, compensation policy, recruitment and selection, performance appraisal and industrial relations has considered as HRM aspects

\section{Methodology}

In order to achieve the research objectives, a set of research questions are developed for collecting opinions and the research hypotheses are made to explore the opinions of employees of the pharmaceutical companies. The self-administered questionnaires have been distributed to employees working in different pharmaceutical companies. There are five parts of questionnaires. Part one, two, three, and four consist of demographic variables, Human Resource Management (HRM) Practices, Customer satisfaction.

English version questionnaires are translated into Nepalese version questionnaire set for greater participation and responses from Nepalese employees. All the items are measured on a five-point Likert-type scale from "Strongly agree (5))" to" Strongly disagree (1))". For the study purpose, descriptive research design is used. Descriptive statistical tools such as 


\title{
Nepal Journal of Multidisciplinary Research (NJMR)
}

\author{
Vol. 4, No. 4, December 2021. Pages: 63-69 \\ ISSN: 2645-8470 (Print), ISSN: 2705-4691 (Online) \\ DOI: https://doi.org/10.3126/njmr.v4i4.43210
}

frequencies, mean, standard deviation to assess the perception of organizational justice and employee work outcomes. Similarly, correlation coefficient and regression are used as statistical tools. To prove the assumptions of regression model, Kolmogorov Smirnov test is used for normality test and multicollinearity is tested using collinearity statistics (VIF). Factor analysis and some of the inferential statistics such as Analysis of Variance (ANOVA), are used to analyse the data. Purposive sampling techniques are followed to gather the perceptions of the respondents. This study covers 47 pharmacituals companies. A total of 840 copies of questionnaires are distributed. In total, 765 questionnaires have been returned, comprising a response rate of 91.10 percent. To investigate the research questions, an empirical study is conducted and based on the research model; the research hypotheses of this study are tested.

\section{Findings \& Discussion}

\section{Nature of human resource practices in Nepal}

One of the important objectives of this study is to identify the status of HRM practices in Nepalese organizations. Human resource management practice of any organization is important section which determines the performance of organization. This section presents results regarding status of HRM practices (in terms of HR planning, selection, training, performance appraisal, career planning compensation, and employee participation) in Nepalese organizations

Table 1 General Descriptive of Human resource practices in Overall Sample $(\mathbf{N}=576)$

\begin{tabular}{|l|l|l|l|l|}
\hline practices Components & Minimum & Maximum & Mean & SD \\
\hline Human Resource Planning & 1 & 5 & 3.51312 & 0.96411 \\
\hline HR selection practices s & 1 & 5 & 3.35373 & 0.94393 \\
\hline Training & 1 & 5 & 3.18924 & 0.92547 \\
\hline Performance appraisal & 1 & 5 & 3.30556 & 0.85389 \\
\hline Career Planning & 1 & 5 & 3.25595 & 0.8241 \\
\hline Compensation & 1 & 5 & 3.31285 & 0.85697 \\
\hline Employee Participation & 1 & 5 & 3.32755 & 0.79895 \\
\hline
\end{tabular}

The results show that the mean on Human Resource Planning practices is 3.51312 with S.D. $=0.96411$, the mean for HR selection practices is 3.35373 with S.D. $=0.94393$, the mean for Training practices is 3.18924 with S.D. $=0.92547$, the mean for Performance appraisal practices is 3.30556 with S.D. $=0.85389$, the mean for Career Planning practices is 3.25595 with S.D. $=0.8241$, the mean for Compensation practices is 3.31285 with S.D. $=0.85697$ and the mean for Employee Participation practices is 3.32755 with S.D. $=0.79895$ respectively.

The result shows that based on mean value, high level of Human Resource Planning practices, that is followed by HR selection, employee participation, compensation, performance appraisal and career planning. However, the lowest mean of training shows low level of training practices among the Nepalese employees.

\section{Customer Satisfaction}

Customer satisfaction was one important variables of the non-financial performance of the 


\title{
Nepal Journal of Multidisciplinary Research (NJMR)
}

\author{
Vol. 4, No. 4, December 2021. Pages: 63-69 \\ ISSN: 2645-8470 (Print), ISSN: 2705-4691 (Online) \\ DOI: https://doi.org/10.3126/njmr.v4i4.43210
}

company for this study so the study explored its frequency distribution. The data presented in the Table No. ... shows the distribution of mean value, standard deviation, $t$ value and $p$ value. The study had done the analysis of frequency distribution of response on different variables of customer satisfaction which found that $69.4 \%$ agreed that their company was very concerned with the satisfaction of customers with 3.88 mean value and 0.818 standard deviation. Similarly, regarding the collection of information from customers to know the needs, $53.3 \%$ gave the neutral answer, only $27.1 \%$ agreed and $12.3 \%$ strongly agreed with 3.44 mean value and 0.813 standard deviation. In the role of company management to provide good services to avoid dissatisfaction of customers, $44.1 \%$ gave the neutral answer, $38.2 \%$ agreed and $12.2 \%$ strongly agreed having with 3.57 mean values and 0.784 standard deviation. The statistical analysis of One sample t-test shows that there was significant difference in individual variables of customer satisfaction because the $p$ value of all variables were less than 0.05 significant levels.

Table 2: Employees' Perception towards of - customer satisfaction

\begin{tabular}{|c|c|c|c|c|c|}
\hline $\begin{array}{l}\text { S. } \\
\text { N. }\end{array}$ & Scale & $\begin{array}{l}\text { Me } \\
\text { an }\end{array}$ & S.D & $\mathbf{T}$ & $\begin{array}{l}\text { Sig. } \\
\text { (2- } \\
\text { taile } \\
\text { d) }\end{array}$ \\
\hline 1 & $\begin{array}{l}\text { Satisfaction of customers/clients is preferred concern of our } \\
\text { organization }\end{array}$ & $\begin{array}{l}3.8 \\
8\end{array}$ & $\begin{array}{l}0.8 \\
18\end{array}$ & $\begin{array}{l}113 . \\
654\end{array}$ & $\begin{array}{l}.00 \\
0\end{array}$ \\
\hline 2 & $\begin{array}{l}\text { This company collects information from customers to know } \\
\text { their needs }\end{array}$ & $\begin{array}{l}3.4 \\
4\end{array}$ & $\begin{array}{l}0.8 \\
13\end{array}$ & 101. & $\begin{array}{l}.00 \\
0\end{array}$ \\
\hline 3 & $\begin{array}{l}\text { Company management tries to provide good services to } \\
\text { avoid dissatisfaction of customers }\end{array}$ & $\begin{array}{l}3.5 \\
7\end{array}$ & $\begin{array}{l}0.7 \\
84\end{array}$ & $\begin{array}{l}109 . \\
152\end{array}$ & $\begin{array}{l}.00 \\
0\end{array}$ \\
\hline & Average & $\begin{array}{l}3.6 \\
3\end{array}$ & $\begin{array}{l}0.8 \\
1\end{array}$ & & \\
\hline
\end{tabular}

Source: Field Survey, 2017

The effort of company to make their customer satisfy was moderately satisfactory because still minimum $26.4 \%$ to $53.3 \%$ respondents were in neutral position to response in the customer satisfaction. The mean distribution also shows that minimum mean value was 3.44 to maximum 3.88 with average mean was 3.63 and 0.81 standard deviation.

The result indicates that the pharmaceutical companies were doing good work to satisfy their customers. Though, still there was need to care the needs and queries of customers to improve in the organizational performance of companies. Customers satisfaction should be the first priority of companies to increase their profit and organizational performances.

\section{Effect of HRM practice on Customer satisfaction (Non-Financial Performance)}

The study had analyzed the effect of HRM practices on customer satisfaction from the regression analysis. The data presented in the Table 3 shows R Square is .305 which indicates that the HRM practices explain only $30.5 \%$ of the variation in the customer satisfaction as non-financial performance of companies. The adjusted R Square value is .296 which means that the HRM practices contributed by $29.6 \%$ in customer satisfaction of surveyed pharmaceutical companies. 


\section{Nepal Journal of Multidisciplinary Research (NJMR)}

Vol. 4, No. 4, December 2021. Pages: 63-69

ISSN: 2645-8470 (Print), ISSN: 2705-4691 (Online)

DOI: https://doi.org/10.3126/njmr.v4i4.43210

Table 3: Effect of HRM practice on Customer satisfaction

\begin{tabular}{|l|l|l|l|l|l|}
\hline Model Summary & \multicolumn{4}{l|}{ (Adjusted } \\
Model & $\mathrm{R}$ & $\mathrm{R}$ Square & $\begin{array}{l}\text { Std. Error of the } \\
\text { Estimate }\end{array}$ & Durbin-Watson \\
\hline 1 & $.552^{\mathrm{a}}$ & .305 & .296 & 1.75635 & 1.277 \\
\hline
\end{tabular}

a. Predictors: (Constant), q16_total, q10_total, q15_total, q12_total, q14_total, q11_total, q13_total

b. Dependent Variable: q17.2custorSatisfaction_total

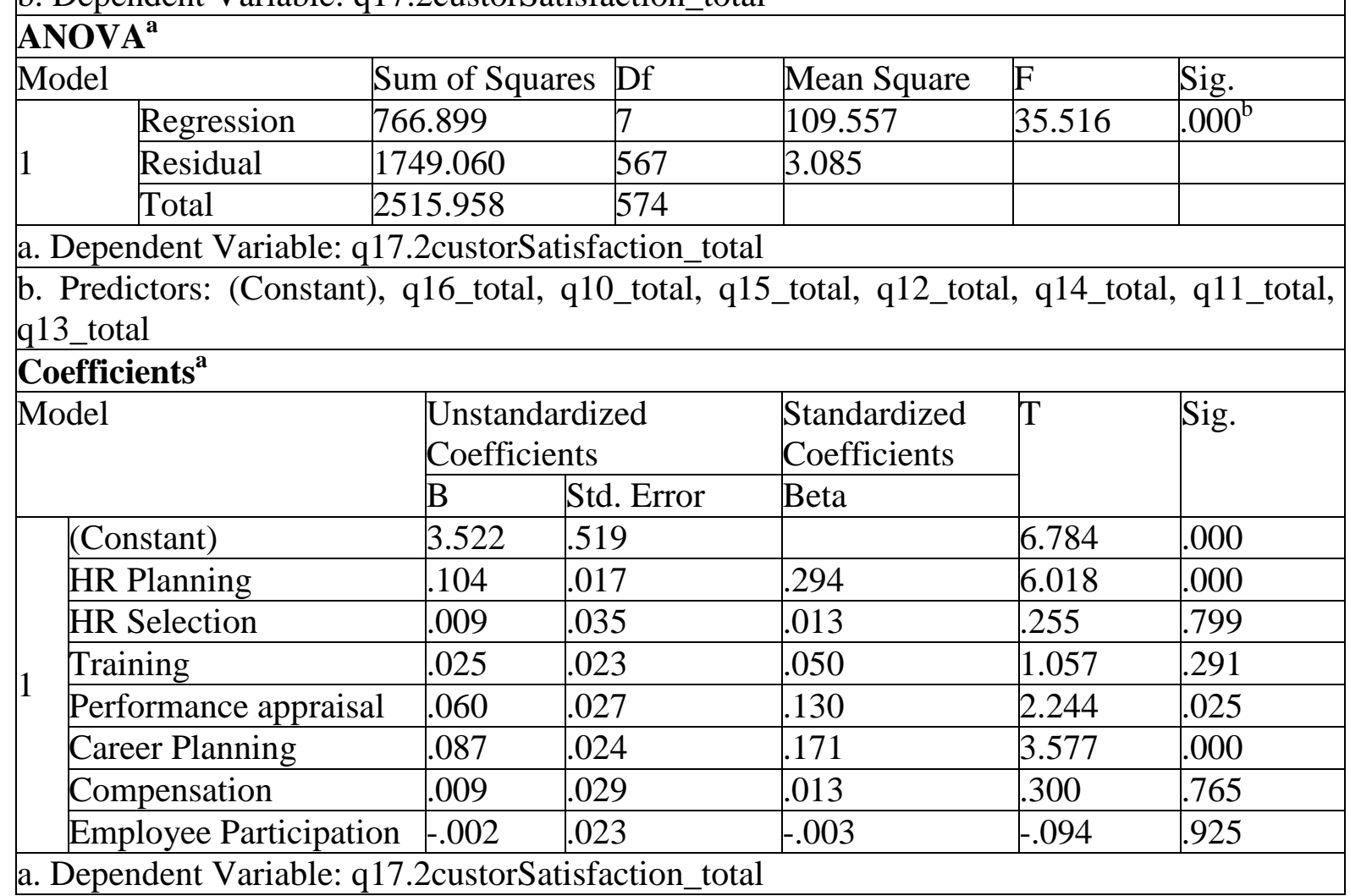

Source: Field Survey, 2017

The effect of individual variables of HRM practices found that there was significant effect of HR Planning $(\mathrm{p}=.000)$, performance appraisal $(\mathrm{p}=.025)$, Career Planning $(\mathrm{p}=.000)$ whereas there was no effect of HR selection $(p=.799)$, Training $(p=.291)$, Compensation $(p$ $=.765)$ and Employee Participation $(\mathrm{p}=.925)$.

The effect of HRM practices was not very effective because in the current practices, there was only $29.6 \%$ contribution of HRM practices on customer satisfaction. Customers are the main source of free advertisement of product and service quality as well as profit of companies. So, HR department should develop the specific plan to increase the number of customers as well as the plan to increase their level of satisfaction.

\section{Conclusion}

From the analysis and observation of all collected data, it was found that majority of 


\title{
Nepal Journal of Multidisciplinary Research (NJMR)
}

\author{
Vol. 4, No. 4, December 2021. Pages: 63-69 \\ ISSN: 2645-8470 (Print), ISSN: 2705-4691 (Online) \\ DOI: https://doi.org/10.3126/njmr.v4i4.43210
}

respondents had given the neutral answer in the most of activities (HR planning, HR selection, Training, performance appraisal, career planning, compensation, employee participation, financial performance) of human resource management of their concerned organization. In the Nepalese context, there is problem to get the opportunity of employment. Comparatively, majority of people have got the employment in non-government sectors; basically private sectors so they do not want to speak about the internal issues or any problem of their organization. The main purpose of this study was to determine the role of HRM practices and impact on Customers satisfaction in the pharmaceutical companies of Nepal. The study sought to determine the mediation of organizational outcome in the relationship between human resource practices and on Customers satisfaction. The study also sought to establish whether the joint effect of human resource practices on Customers satisfaction was greater than the individual effect of each predictor variable.

The results of further analysis revealed that human resource practices mediate the relationship between on Customers Satisfaction Similarly The effect of HRM practices was not very effective because in the current practices, there was only $29.6 \%$ contribution of HRM practices on customer satisfaction. Customers are the main source of free advertisement of product and service quality as well as profit of companies. So, HR department should develop the specific plan to increase the number of customers as well as the plan to increase their level of satisfaction. These results suggest that Nepalese pharamicutal company should be proactive in developing human resource practices in order to enhance the influence of on Customers satisfaction.

\section{References}

Beardwell, I., Holden, L., and Claydon, T. (2004).Human Resource Management a Contemporary Approach, 4th Ed, Harlow: Prentice Hall.

Buck, J. M. Watson, J. L. (2002). Retaining staff employees: The relationship between Human Resources Management Strategies and Organizational Commitment, Innovative Higher Education, Vol: 26 No. 3, 175-193.

DeCenzo, D. A. and Robbins, S. P. (1996).Personnel/Human Resource Management.3rd Ed. New Delhi: Prentice-Hall of India Pvt. Ltd.

Denisi, A. S., and Griffin, R. W.(2009). Human Resource Management, 2nd Ed, Houghton Mifflin Co., USA. Dessler, G. (2007). Human Resource Management, Prentice Hall of India Private Limited, New Delhi.

Edgar, F. and Greare, A. (2005). HRM practice and employee attitudes: Different measuresdifferent results. Personnel Review, Vol.34, No.5, pp.534-549.

F e r n a n d e z, C. J.( 1992). Solider quality and job performance in team tasks.Social science Quarterly, Vol .73, pp. 253-265.

Gardner, T. Moynihanand, L. and Wright, P. (2007).The influences of human resource practices and collective affective organizational commitment on aggregate voluntary turnover, CAHRS Working Paper, Cornell University, 2007.

G a r c ia, M. (2005). Training and business performance: The Spanish case, International Journal of Human Resource Management, Vol.16, pp.1691-1710.

Huselid, M. A. (1995). The impact of human resource management practices on turnover, productivity, and corporate financial performance, Academy of Management Journal, Vol. 38, 635-672. 


\section{Nepal Journal of Multidisciplinary Research (NJMR)}

Vol. 4, No. 4, December 2021. Pages: 63-69

ISSN: 2645-8470 (Print), ISSN: 2705-4691 (Online)

DOI: https://doi.org/10.3126/njmr.v4i4.43210

$\mathrm{K}$ a t o u, A. A. and B u d w a r, P. S. (2007). The effects of human resource management policies on organizational performance in Greek manufacturing firms. Thunderbird International Business Review, Vol. 49, No. 1, pp.1-35.

Klaus, T. LeRouge, C. and Blanton, J. E. (2003). An examination of the relationships between select nature of work characteristics and organizational commitment of IT professionals, Special Interest Group on Computer Personnel Research Annual Conference, Session 3.2, 147-149.

Mondy, R. W., and Noe, R. M.(2005). Human Resource Management, 9th Ed, Pearson Education, Inc.

Senyucel, Z.(2012) Managing Human Resources in the 21st Century. Available at http://www.bookboon.com; Accessed on 23/11/2012.

Shaw, J. D. Delery, J. E. Jenkins, G. D. Jr. and Gupta, N. (1998) An organization-level analysis of voluntary and involuntary turnover, Academy of Management Journal, Vol. 1, No. 5, 511-525. 